\title{
RANCANG BANGUN KEBIJAKAN PENGEMBANGN BUDIDAYA LELE MELALUI PENDEKATAN MODEL DINAMIK
}

\section{Constructive Design for Catfish Aquaculture Development Policy Through Dynamic Model Approach}

\author{
Budi Wardono' dan Prayudi Budi Utomo² \\ ${ }^{1}$ Balai Besar Penelitian Sosial Ekonomi Kelautan dan Perikanan \\ JI. KS. Tubun Petamburan VI Jakarta 10260 \\ Telp. (021) 53650162, Fax. (021)53650159 \\ ${ }^{2}$ Kepala Seksi Jaringan Distribusi, Ditjen P2HP \\ Email: budi_ward@yahoo.com \\ Diterima 27 Maret 2013 - Disetujui 29 Nopember 2013
}

\begin{abstract}
ABSTRAK
Lele merupakan salah satu komoditas perikanan ekonomis penting yang mendapat prioritas dalam Program Minapolitan Kementerian Kelautan dan Perikanan, terutama di Kabupaten Gunungkidul. Penelitian ini dilakukan pada tahun 2011 yang berlokasi di Propinsi Daerah Istimewa Yogyakarta. Tujuan penelitian adalah menyusun model kebijakan pengembangan perikanan budidaya Ikan Lele untukmendukung produksi perikanan budidaya melalui pendekatan model dinamik. Teknik analisis ini berasumsi bahwa apabila sistem perikanan dipertahankan, permintaan Ikan Lele akan mengalami kenaikan. Hasil simulasi menunjukkan bahwa permintaan meningkat dan puncaknya terjadi pada tahun ke 4. Sementara itu, pasokan dari luar daerah terus meningkat pada tahun ke 4 hingga ke 10. Fluktuasi harga terjadi, tahun ke $3 \mathrm{hHarga}$ lele mengalami penurunan akibat banyaknya produksi lokal terjadi pada tahun ke-3., namun pPada tahun ke 5 harga mengalami kenaikan akibat kekurangan pasokan. Oleh karena itu, diperlukan kebijakan peningkatan produktivitas dan pendapatan usaha budidaya lele dengan memanfaatkan lahan-lahan potensial maupun meningkatan produktifitas usaha.
\end{abstract}

Kata Kunci: lele, pasokan, minapolitan, rancang bangun, model dinamik

\begin{abstract}
Catfish is one of the priority product of fisheries commodity in "Minapolitan" Program introduced by the Ministry of Marine Affairs and Fisheries, particularly in Gunungkidul District, Yogyakarta Province. The study was conducted during 2011 to 2012. .This study aimed to construct the policy model for Catfish aquaculture development to support aquaculture production by using dynamic modelling approache. Technique analysis assumed that Catfish demand will increase when existing fisheries system could be maintained. Finding shows that the demand sharply increased on the fourth year of project. Meanwhile, Catfish supply from other region would be increase on the fourth year and tenth year. Catfish price has decreased on the third year due to over supply of local production. However, Catfish price increased on the fifth year due to less supply of the local product. Therefore, appropriate strategies needed to encourage increased productivity and farmers income by revitalize the potential land and increase business productivity.
\end{abstract}

Keywords: catfish, supply, minapolitan, dynamic model 


\section{PENDAHULUAN}

Arah kebijakan pembangunan bidang kelautan dan perikanan dan kelautan di Provinsi Daerah Istimewa Yogyakarta ditujukan untuk mengintegrasikan antar sub sistem perbenihan, produksi ikan konsumsi, penanganan pasca panen dan diversifikasi produk, perikanan dan kelautan, penyediaan pakan alternatif dan penguatan kelembagaan usaha; meningkatkan kualitas sumberdaya manusia; dan memperluas jaringan pemasaran. Permasalahan yang selama ini muncul dalam pengembangan sektor perikanan di DIY adalah: teknologi dan manajemen di sub sistem usaha perikanan yang masih bersifat tradisional; produksi perikanan belum mampu mengimbangi kebutuhan ikan pada masyarakat di Provinsi DIY, sehingga $70 \%$ kebutuhan produk masih didatangkan dari luar daerah; masih rendahnya kualitas SDM, masih rendahnya daya saing produk; belum optimalnya kelembagaan pelaku usaha, ketersediaan sarana dan prasarana yang belum memadai, masih adanya konflik kepentingan antara subsektor terkait dalam penggunaan sumberdaya esensial seperti sumberdaya lahan dan air; dan masih terbatasnya akses permodalan dan pengembangan pasar (Dinas KP DIY, 2011).

Produk perikanan budidaya di wilayah DIY dan sekitarnya belum dapat disediakan dari wilayah Yogyakarta sendiri, namun sebagian besar masih didatangkan dari luar wilayah Yogyakarta. Untuk memenuhi kebutuhan konsumsi harian masyarakat Yogyakarta, diperlukan pasokan lele sebesar 12-16 ton per hari (Dinas KP DIY. 2011). Sementara, sumbangan petani ikan budidaya di Yogyakarta hanya marnpu memberikan sekitar $30 \%$ dari total permintaan atau kurang lebih 4,2 ton per hari. Kekurangan kebutuhan ikan lele tersebut, saat ini dipenuhi dengan cara mendatangkannya dari wilayah Provinsi Jawa Tengah, yaitu dari Boyolali $(60 \%)$ dan sisanya wilayah Provinsi Jawa Timur (10\%).

Diperlukan strategi untuk menciptakan proporsi pasokan ikan budidaya di Yogyakarta yang ideal dengan memperbesar peranan pelaku lokal, mendorong schedulling rantai pasok komoditi perikananan budidaya untuk pemenuhan keberlanjutan pasokan ikan, dan mendorong tersedianya sarana-prasarana untuk mendukung proses supply chain, serta optimasi pengembangan sistem informasi. Untuk mewujudkan hal tersebut tentunya memerlukan dukungan berbagai pihak, mulai dari aspek produksi, industri hilir (handling and processing), hingga ke pemasaran/ perdagangan (Widodo et al., 2011). Salah satu upaya yang dapat dilakukan, antara lain adalah mengkaji dan merancang model logistik dan supply chain untuk mendukung kegiatan produksi dan perdagangan komoditi perikanan budidaya agar mampu mewujudkan kegiatan produksi dan perdagangan perikanan budidaya secara optimal dan dapat memberikan sumbangan bagi implementasi kebijakan penyelenggaraan program pembangunan di sektor kelautan dan perikanan, khususnya dalam hal program peningkatan konsumsi ikan masyarakat Yogyakarta.

Proses pendistribusian perikanan terkait erat dengan konsep SCM (Supply Chain Model). Model supply chain komoditi kelautan perikanan mempunyai struktur lebih komplek dari pada model supply chain produk pada umumnya. Struktur Jaringan dalam supply chain komoditi perikanan dan kelautan melibatkan banyak pihak, diantaranya adalah nelayan, pedagang kecil, pedagang besar, pabrik, eksportir, pemerintah hingga masyarakat sebagai konsumen akhir. Struktur supply chain pada prakteknya sangat dipengaruhi kondisi geografis, politik, ekonomi, sosial dan budaya pada masing-masing pelaku yang terlibat dalam seluruh rantai proses dari hulu (upstream) hingga hilir (downstream). Salah satu struktur rantai supply chain komoditi perikanan. Sebagai contoh, di negara maju seperti Amerika dan Jepang telah jauh berkembang dibanding Indonesia. Negara tersebut mampu sukses dalam menerapkan SCM karena adanya koordinasi, kerjasama dan kolaborasi ditunjang penerapan teknologi antarpelaku yang terlibat kegiatan jual beli atau bisnis dari hulu hingga hilir (Widodo et al., 2011).

Untuk itu dilakukan penelitian dengan tujuan untuk menghasilkan model kebijakan pengembangan budidaya lele guna mendukung peningkatan produksi dan perdagangannya yang dibangun melalui pendekatan model dinamik.

\section{METODOLOGI}

\section{Lokasi dan Waktu Penelitian}

Penelitian dilakukan di Wilayah Propinsi Daerah Istimewa Yogyakarta (DIY) yang meliputi lima wilayah kabupaten dan kota (Yogyakarta, Bantul, Sleman, Gunung Kidul, dan Kulon Progo). Pengambilan data dilakukan dengan menggunakan sampel pelaku-pelaku usaha perikanan di lima wilayah kabupaten dan kota. Penelitian dilakukan 
pada tahun 2011 yaitu sejak bulan Februari hingga Mei 2011.

\section{Pendekatan Analisis}

Sistem Dinamik cocok digunakan untuk melihat kecenderungan dinamik secara umum, dalam kondisi apa sistem secara keseluruhan, apakah sistem stabil atau tidak, fluktuasi, tumbuh, menurun, mengoreksi diri atau dalam kesetimbangan (Meadows, 1980 dalam Sitompul, 2009). Sumberdaya perikanan merupakan sumberdaya yang bersifat dinasmis, sehingga pendekatan dinamis perlu dilakukan untuk melihat interaksi didalam sistem (Fauzi dan Anna, 2005). Pendekatan sistem dinamik merupakan salah satu metode yang digunakan untuk menyelesaikan masalah pada sistem perikanan budidaya. Langkahlangkah pemodelan dengan menggunakan sistem dinamik, yaitu :

a. Identifikasi perilaku persoalan atau memetakan masalah berdasarkan data-data di lapangan. Pemetaan masalah disini meliputi, penentuan variabe-variabel yang ada dalam sistem industri perikanan. Variabel tersebut diuji dengan menggunakan apakah ada hubungan yang signifikan antara satu variabel dengan variabel yang lain. Penentuan variabel-variabel sistem industri perikanan dilakukan bersama-sama pejabat-pejabat yang menangani masalah industri perikanan di wilayah lokasi penelitian. Pada langkah ini juga dibuat model mental dalam bentuk diagram Simpal Kausal (Causal Loop Diagram)

b. Pembuatan Model computer dari sistem industri perikanan ini (biasa disebut Stock Flow Diagram/SFD) dilakukan berdasarkan model mental yang telah dibuat bersama pejabat Dinas kelautan terkait.

c. Pemasukan data ke dalam model Komputer menggunakan perangkat lunak POWERSIM.

d. Setelah input data, model tersebut disimulasikan yang akan menghasilkan keluaran berupa grafik, yang menunjukan berapa nilai dari masing-masing variabel tersebut setelah di run.

e. Validasi diperlukan untuk menentukan apakah model dan keluarannya tidak menyimpang dari sistem nyatanya. Dilakukan dengan membandingkan data sistem nyata yang berupa grafik dari data statistik dengan keluaran hasil simulasi model yang berupa grafik.

f. Uji sensitifitas dilakukan untuk menentukan faktor-faktor yang berpengaruh (atau yang bi- asa disebut Leverage). Leverage adalah variabel yang bila dirubah sedikit saja akan merubah seluruh sistem. Penentuan faktor-faktor yang berpengaruh (Leverage) ini menjadi langkah yang penting karena pembuatan skenario kebijakan dilakukan dengan memberikan stimulans pada Leverage yang pada akhirnya setelah dilakukan eksperimen akan di idapat kebijakan yang paling optimal.

Menurut Tasrif (2006) dan Sitompul (2009), persoalan yang dapat dengan tepat dimodelkan menggunakan metodologi sistem dinamik adalah masalah yang:

a. Mempunyai sifat dinamik (berubah terhadap waktu) dan;

b. Struktur fenomenanya mengandung paling sedikit satu struktur umpan balik (feedback structure).

\section{Teknik Pengumpulan Data}

Pengumpulan data dilakukan melalui kegiatan: survey lapangan untuk pengamatan dan mendapatkan data atau informasi aktual. Stakeholders yang menjadi obyek pengamatan adalah seluruh pelaku yang terkait dalam rantai pasok komoditi perikanan budidaya lele, mulai dari level produsen (pemasok), proses distribusi, dan kegiatan konsumsi. Focus Group Discussions (FGD) untuk menjaring informasi/data yang diperoleh secara langsung dari stakeholders perikanan budidaya.

Menurut Widodo et al., (2011) dan Djakapermana (2010), dalam model dinamik yang dibangun terdapat enam tahapan yang dilakukan, yaitu:

a. Identifikasi dan definisi masalah.

b. Penyusunan konseptual system, yaitu penyusunan causal loop yang menunjukkan aliran informasi dan cara kerja yang terjadi dalam sistem.

c. Formulasi model, yaitu: menterjemahkan model konseptual ke dalam media computer. Formulasi model dilakukan dengan software POWERSIM.

d. Simulasi dan validasi model, yaitu: model dengan perangkat lunak POWERSIM. Proses menjalankan model disebut dengan simulasi. Model disimulasikan untuk melihat bagaimana perilaku model tersebut yang merupakan gambaran perilaku sistem nyata. 


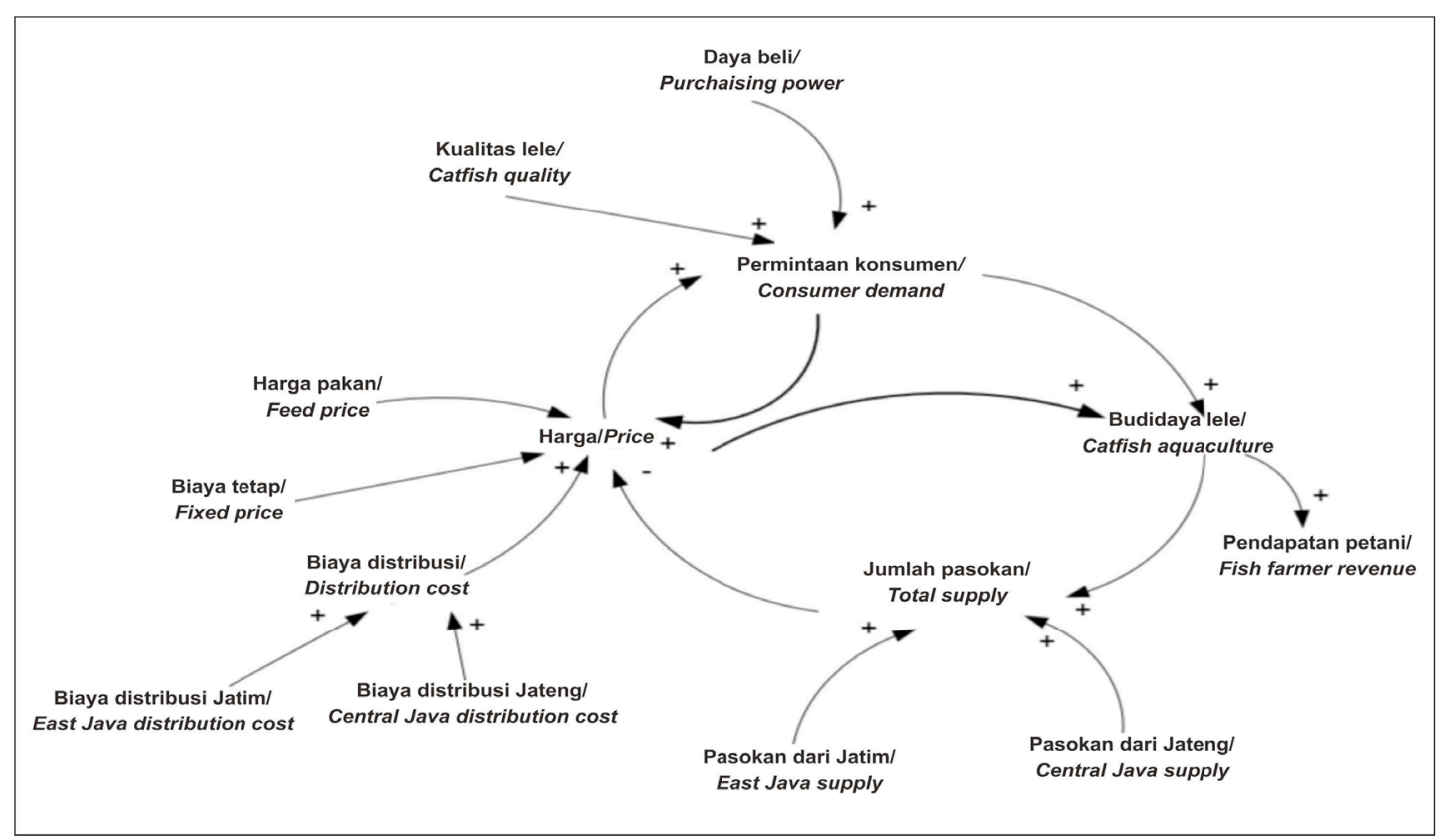

Gambar 1. Hubungan Sebab Akibat dari Masing-Masing Sub System yang diteliti. Figure 1. Causal Loop Diagram of Each Sub System

\section{ANALISIS PERMINTAAN}

Pendekatan model dinamis yang digunakan untuk menghasilkan kebijakan pengembangan budidaya lele disusun berdasarkan model dinamik yang sudah disusun seperti tertera pada Gambar 2. Model tersebut dikembangkan berdasar causal loop hubungan sebab akibat antar sub sistem. Adapun model dinamik yang dibangun bertujuan menganalisis pengembangan komoditas budidaya ikan lele. Model dinamis (Gambar 2) dapat memprediksi kondisi perikanan lele di DIY selama 10 tahun mendatang berdasarkan pada sistem perikanan lele saat ini.

Apabila sistem perikanan lele dipertahankan seperti saat ini, maka permintaan lele di DIY akan mengalami kenaikan permintaan dari tahun ke tahun. Permintaan puncak kenaikan terjadi pada tahun ke 4 sebesar 3.3847 ton (Gambar 3).

Setelah tahun ke 4, permintaan lele di DIY mengalami penurunan lalu stabil. Kenaikan permintaan tersebut diakibatkan oleh peningkatan jumlah penduduk dari tahun ke tahun (Gambar 4) dan fluktuasi jumlah konsumsi lele per kapita per tahun (Gambar 5). Fluktuasi konsumsi per kapita lele dari tahun ke tahun merupakan hasil peramalan berdasarkan pola konsumsi masyarakat DIY tahuntahun sebelumnya.

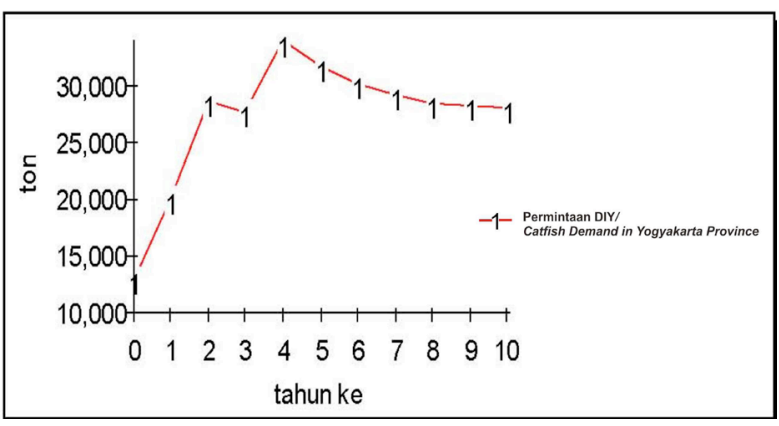

Gambar 3. Permintaan Lele Selama 10 tahun di DIY (ton/tahun).

Figure 3. Catfish Demand for 10 years in Yogyakarta Province (tons/year).

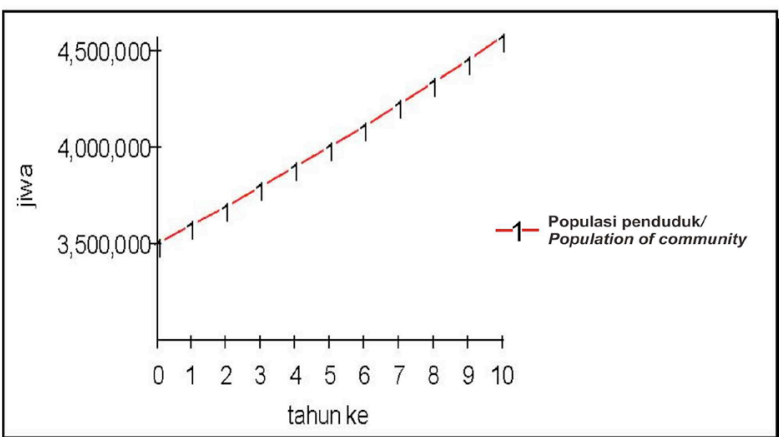

Gambar 4. Perkiraan Perkembangan Penduduk Selama 10 Tahun ke Depan.

Figure 4. Population Growth Estimation for 10 Years (2010-2020). 


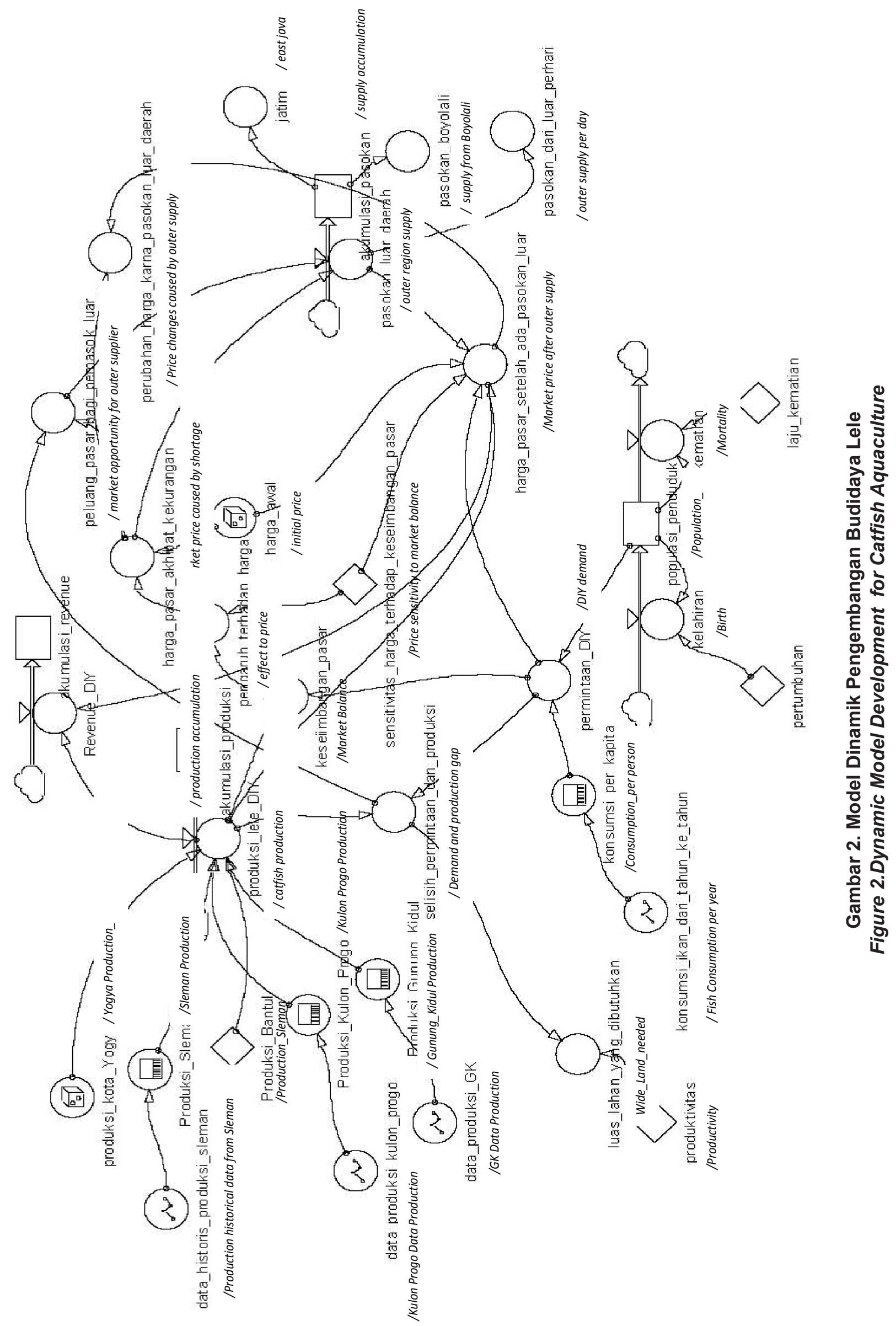


Trend konsumsi lele di DIY selama 10 tahun ke depan akan meningkat sampai tahun ke 4 dan akan relatif stabil sampai tahun ke 10 (Gambar 5).

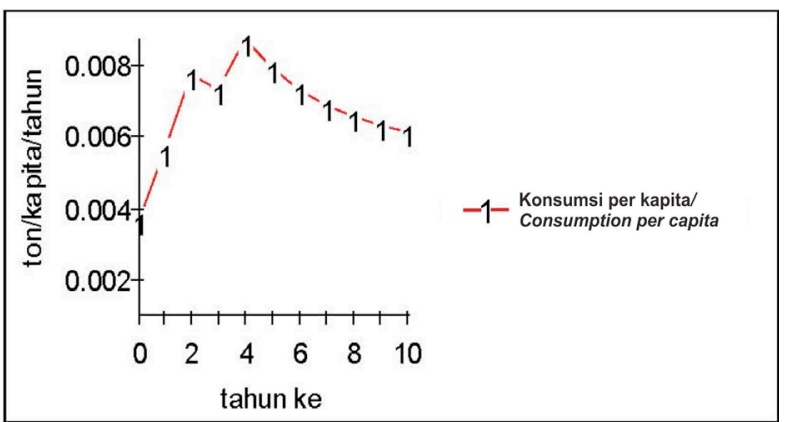

Gambar 5. Tingkat Konsumsi Ikan Lele per Kapita.

Figure 5. Catfish Consumption Level per Capita.

\section{ANALISIS PRODUKSI}

Perkembangan jumlah produksi lele di DIY dapat dilihat pada Gambar 6. Produksi lele di DIY akan mengalami puncak kenaikan pada tahun ke 3, yaitu sebesar 30.118 ton. Produksi lele yang ditunjukan oleh gambar tersebut merupakan hasil penjumlahan semua produksi lele di seluruh Kabupaten dan Kota di DIY berdasarkan pada peramalan sesuai data historis tiap daerah.

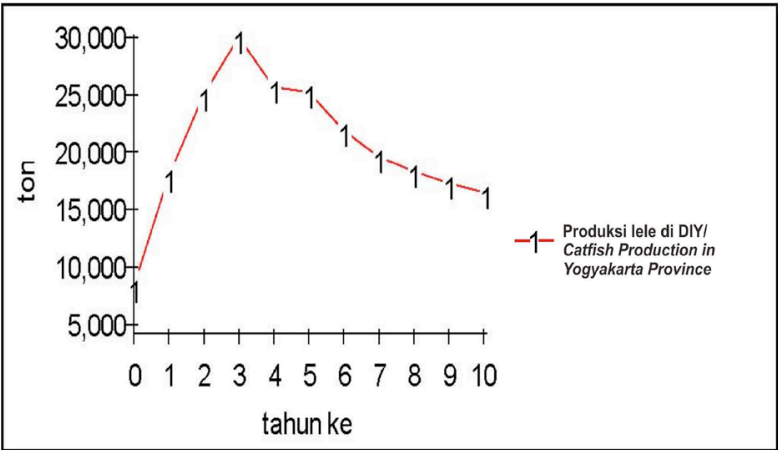

Gambar 6. Tingkat produksi ikan lele (ton/ tahun).

Figure 6. Catfish production levels (tons / year).

Perbandingan produksi lele antar kabupaten dan kota di DIY dapat dilihat pada Gambar 7. Gambar tersebut menujukkan bahwa daerah Gunung Kidul pada tahun ke 2 hingga tahun ke 4 akan menjadi produsen lele terbesar, namun produksinya akan menurun dari tahun ke 4 hingga tahun ke 10. Puncak produksi lele di Kabupaten Gunung Kidul terjadi pada tahun ke 3 sebesar 14.192 ton.
Pada tahun ke 4 hingga tahun ke 10, Kabupaten Sleman akan menjadi produsen lele terbesar melebihi daerah lain di DIY. Puncak kenaikan produksi di Kabupaten Sleman terjadi pada tahun ke 5 sebesar 12.155 ton. Dari simulasi yang dilakukan, Kabupaten Kulon Progo mengalami puncak produksi lele pada tahun ke 1 sebesar 8.168 ton. Produksi lele terendah berada di Kota Yogyakarta karena kurangnya lahan dan minimnya petani. Produksi di Kabupaten Bantul tidak mengalami perubahan karena tidak ada data historis pendukung untuk peramalan. Peramalan jumlah produksi tersebut dilakukan berdasarkan pada data historis tiap daerah lalu dimodelkan dalam model dinamis.

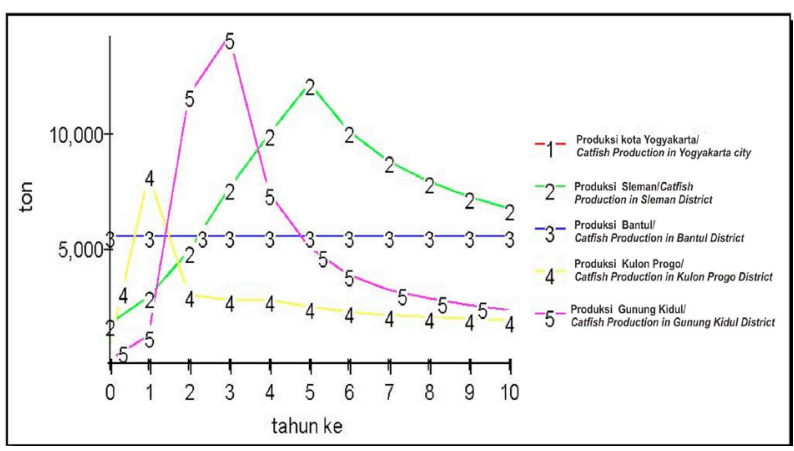

Gambar 7. Pola Produksi Antar Kabupaten Selama 10 Tahun ke Depan.

Figure 7. Production Patterns Among
Districts in Yogyakarta Province
During 10 Years (2010-2020).

Kondisi tersebut harus diantisipasi oleh Dinas KP Propinsi maupun Kabupaten/Kota untuk dapat mencari jalur (path) dari trend penurunan produksi setelah tahun ke 5 . Upaya-upaya yang dilakukan antara lain perluasan lahan potensial menjadi lahan produktif dan penyediaan saran produksi yang memadai, yaitu benih dan pakan, terutama pakan altenatif.

\section{ANALISIS PASOKAN}

Untuk mengantisipasi kekurangan produksi lele di DIY masih diperlukan tambahan pasokan dari luar daerah terutama dari Jawa Tengah dan Jawa Timur. Perkiraan produksi, dan permintaan produk lele dan pasokannya dari luar daerah, selama 10 tahun ke depan seperti tertera pada Gambar 7.

Dari hasil simulasi diketahui jumlah permintaan dari tahun ke tahun sebagaimana ditunjukkan dalam Gambar 8, tidak dapat dicukupi oleh produksi dari dalam DIY. Kekurangan 
kebutuhan tersebut dipenuhi dari Kabupaten Boyolali dan Jawa Timur. Gambar 9 menunjukkan proyeksi perbandingan permintaan, produksi dan pasokan lele dari luar daerah.

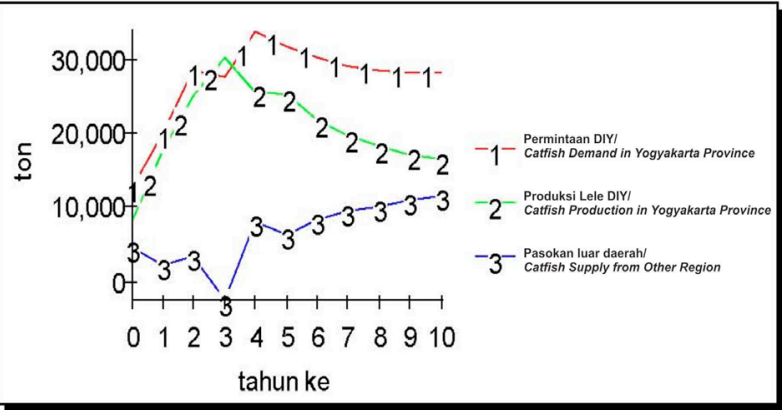

\section{Gambar 8. Pola Produksi, Permintaan dan Pasokan Ikan Lele selama 10 Tahun ke Depan.}

Figure 8. Production, Demand and Supply of Catfish for 10 years.

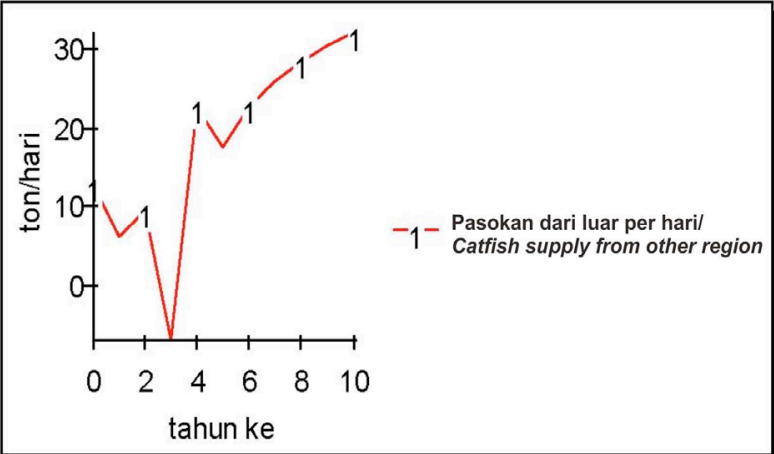

Gambar 9. Proyeksi Pasokan Ikan Lele dari Luar Daerah Selama 10 Tahun.

Figure 9. Catfish Supply Projections of Other Regions For 10 Years.

Permintaan di DIY saat ini belum dapat dipenuhi oleh produksi dari dalam propinsi. Dari simulasi model dinamis, diketahui bahwa permintaan semakin meningkat dan puncaknya terjadi pada tahun ke 4 . Namun pada tahun ke 3 , kebutuhan dapat dipenuhi oleh produksi dalam propinsi, walaupun pada tahun ke 4 sampai ke 10 produksi tersebut mengalami penurunan. Pasokan dari luar daerah mengalami fluktuasi pada tahun ke 1 hingga ke 3 , namun akan terus meningkat pada tahun ke 4 hingga ke 10 akibat produksi DIY yang mengalami penurunan. Perkembangan jumlah pasokan dari luar daerah per hari dapat dilihat pada Gambar 9.

Untuk menanggulangi kekurangan pasokan dari luar daerah, pemerintah dan petani DIY perlu meningkatkan jumlah produksi. Apabila peningkatan tersebut dilakukan dengan penambahan lahan, maka lahan yang perlukan untuk untuk mencukupi permintaan tersebut ditunjukan oleh Tabel 1.

Apabila kekurangan produksi ingin dipenuhi dari produksi lokal, hasil simulasi menunjukkan tambahan luas lahan yang dibutuhkan seperti pada Gambar 10.

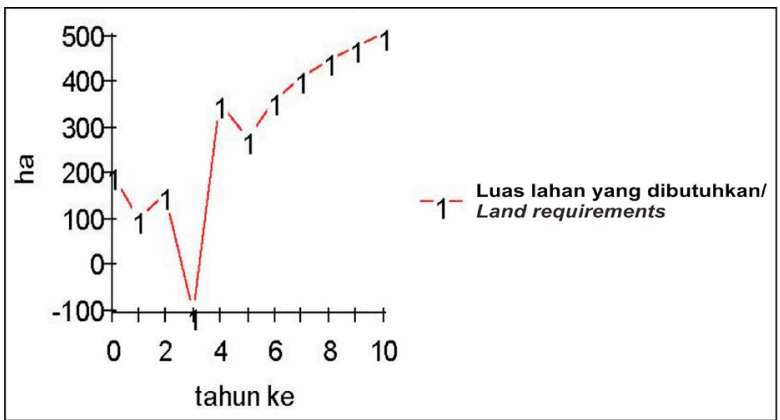

Gambar 10. Hasil Simulasi Kebutuhan Lahan Untuk Budidaya selama 10 Tahun Ke Depan.

Figure 10. Requirement Land Simulation for Aquaculture Land During10 Years.

Kebutuhan lahan untuk budidaya meningkat pada tahun ke-4 dan tahun-tahun berikutnya sebanding dengan kekurangan jumlah pasokan ikan. Berdasarkan hasil simulasi, untuk mencukupi kebutuhan lokal (menutup jumlah pasokan ikan dari luar daerah), maka diperlukan luas lahan seperti pada Tabel 1.

\section{PERKEMBANGAN HARGA}

Harga lele di pasar DIY berkisar antara Rp 10.200 hingga Rp 13.000 per kilogram. Berdasarkan hasil simulasi yang dilakukan, apabila terjadi kekurangan pasokan maka akan mengakibatkan kenaikan harga. Perkembangan harga akibat kekurangan pasokan di DIY terjadi apabila tidak ada pasokan dari luar daerah. Hal ini dapat dilihat pada Gambar 11

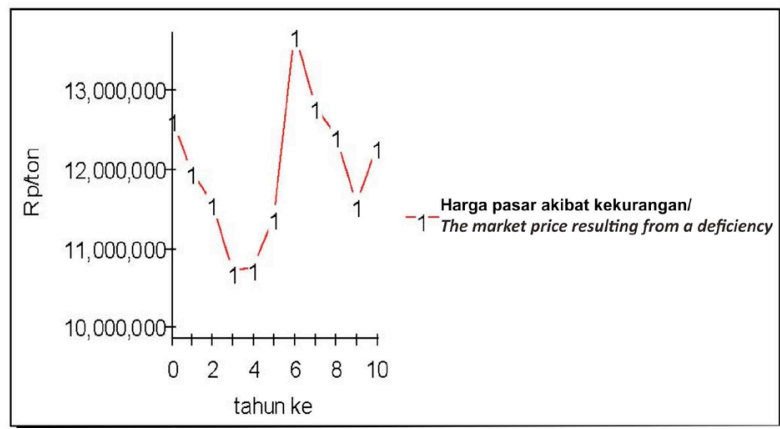

Gambar 11. Simulasi Harga Ikan untuk 10 Tahun Ke Depan.

Figure 11. Catfish Price Simulation for 10 Years. 
Tabel 1. Hasil Simulasi Produksi Permintaan, Pasokan Luar Daerah dan Kebutuhan Lahan untuk Budidaya Lele Selama 10 tahun ke Depan.

Table 1. Simulation for Production, Demand, Supply of Other Regions and Land Requirements for Catfish Aquaculture during 10 years.

\begin{tabular}{cccccc}
\hline Tahun/ & $\begin{array}{c}\text { Permintaan DIY } \\
\text { (ton/tahun)/ } \\
\text { Yatfish Demand } \\
\text { in Yogyakarta } \\
\text { Province (Ton/ } \\
\text { Year) }\end{array}$ & $\begin{array}{c}\text { Produksi DIY (ton/ } \\
\text { tahun)/ } \\
\text { Catfish Production in } \\
\text { Yogyakarta Province } \\
\text { (Ton/Year) }\end{array}$ & $\begin{array}{c}\text { Pasokan luar daerah/ } \\
\text { Catfish Supply from } \\
\text { Other Region }\end{array}$ & $\begin{array}{c}\text { Lahan } \\
\text { dibutuhkan / } \\
\text { Land }\end{array}$ & $\begin{array}{c}\text { Requirements } \\
\text { (Ha)/ }\end{array}$ \\
\hline 0 & $12,886.88$ & $8,275.75$ & $4,611.13$ & 12.63 & 199.05 \\
1 & $20,095.01$ & $17,849.51$ & $2,245.50$ & 6.15 & 96.93 \\
2 & $28,565.47$ & $25,065.99$ & $3,499.48$ & 9.59 & 151.07 \\
3 & $27,607.18$ & $30,117.61$ & $-2,510.43$ & -6.88 & -108.37 \\
4 & $33,847.36$ & $25,681.20$ & $8,166.16$ & 22.37 & 352.52 \\
5 & $31,583.53$ & $25,196.49$ & $6,387.03$ & 17.50 & 275.72 \\
6 & $30,077.16$ & $21,806.31$ & $8,270.85$ & 22.66 & 357.04 \\
7 & $29,095.22$ & $19,669.68$ & $9,425.54$ & 25.82 & 406.88 \\
8 & $28,492.00$ & $18,225.06$ & $10,266.94$ & 28.13 & 443.20 \\
9 & $28,171.66$ & $17,202.64$ & $10,969.02$ & 30.05 & 473.51 \\
10 & $28,068.53$ & $16,451.88$ & $11,616.65$ & 31.83 & 501.47 \\
\hline
\end{tabular}

Sumber : Analisis data

Gambar 11 menunjukkan bahwa terjadi fluktuasi harga dari tahun ke tahun. Pada tahun ke 3, harga lele per ton mengalami penurunan akibat banyaknya produksi dari dalam DIY, namun pada tahun ke 5 harga mengalami kenaikan tajam akibat kekurangan pasokan. Pasokan dari luar daerah dapat menurunkan harga jual lele di DIY. Perbandingan harga jual lele sebelum dan sesudah ada pasokan dari luar daerah dapat dlilihat pada Gambar 12.

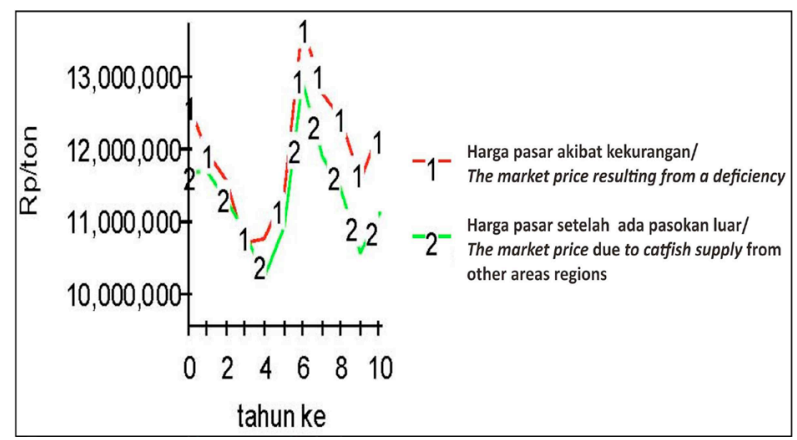

Gambar 12. Simulasi Perbedaan Harga Akibat Adanya Pasokan Ikan Dari Luar Daerah.

Figure 12. Simulation for Price Differentiations Due to Catfish Supply from Other Regions.

\section{PENUTUP}

Kebijakan pengembangan budidaya Lele dipengaruhi oleh faktor permintaan, produksi dan pasokan ikan dari luar daerah. Kebijakan yang diperlukan untuk pemenuhan produksi ikan di DIY, antara lain perluasan lahan budidaya dari lahanlahan potensial dibeberapa daerah yang memenuhi kriteria untuk budidaya. Dalam jangka pendek, pemenuhan kebutuhan lokal dengan pasokan lele dari luar daerah tidak dapat dihindarkan. Meskipun trend jumlah pasokan lele dari luar daerah semakin besar, tetapi tetap diperlukan kebijakan-kebijakan untuk meningkatkan produksi local melalui pengembangan budidaya lele di DIY. Kebijakan-kebijakan ini adalah perluasan lahan usaha dan dipenuhi sarana dan prasarana antara lain benih yang berkualitas, dan pakan lokal yang kompetitif. Laju kebutuhan ikan lokal dipengaruhi oleh permintaan, jumlah populasi dan konsumsi per kapita. Potensi peningkatan konsumsi ikan per kapita akan mendorong peningkatan permintaan ikan. Sementara dalam realitasnya, tingkat konsumsi ikan per kapita di DIY masih rendah, sehingga diperlukan kebijakan-kebijakan pemerintah yang kuat untuk mendorong peningkatan produksi di masa yang akan datang. 


\section{DAFTAR PUSTAKA}

Badan Pusat Statistik Propinsi DIY. 2011. DIY Dalam Angka. Badan Pusat Statistik. Yogjakarta

Dinas Kelautan dan Perikanan Propinsi DIY. 2011. Laporan Tahunan Dinas Kelautan dan Perikanan Propinsi DIY.

Djakapermana, R.D. 2010. Pengembangan Wilayah Melalui Pendekatan Kesisteman. IPB Press. Bogor.

Fauzi, A., dan S. Anna. 2005. Pemodelan Sumberdaya Perikanan dan Kelautan untuk Analisis Kebijakan. PT. Gramedia Pustaka Utama. Jakarta.
Sitompul, R.F. 2009. Merancang Model Pengembangan Masyarakat Pedesaan Dengan Pendekatan System Dynamics. Lembaga IImu Pengetahuan Indonesia. Jakarta.

Widodo K.H., K. Pramudya dan A. Abdullah. 2011. Supply Chain Management Agroindustri yang Berkelanjutan. Penerbit Lubuk Agung. Bandung

Tasrif, M. 2006. Analisis Kebijakan Menggunakan Model System Dynamics. Program Magister Studi Pembangunan. Institut Teknologi Bandung. Bandung. 


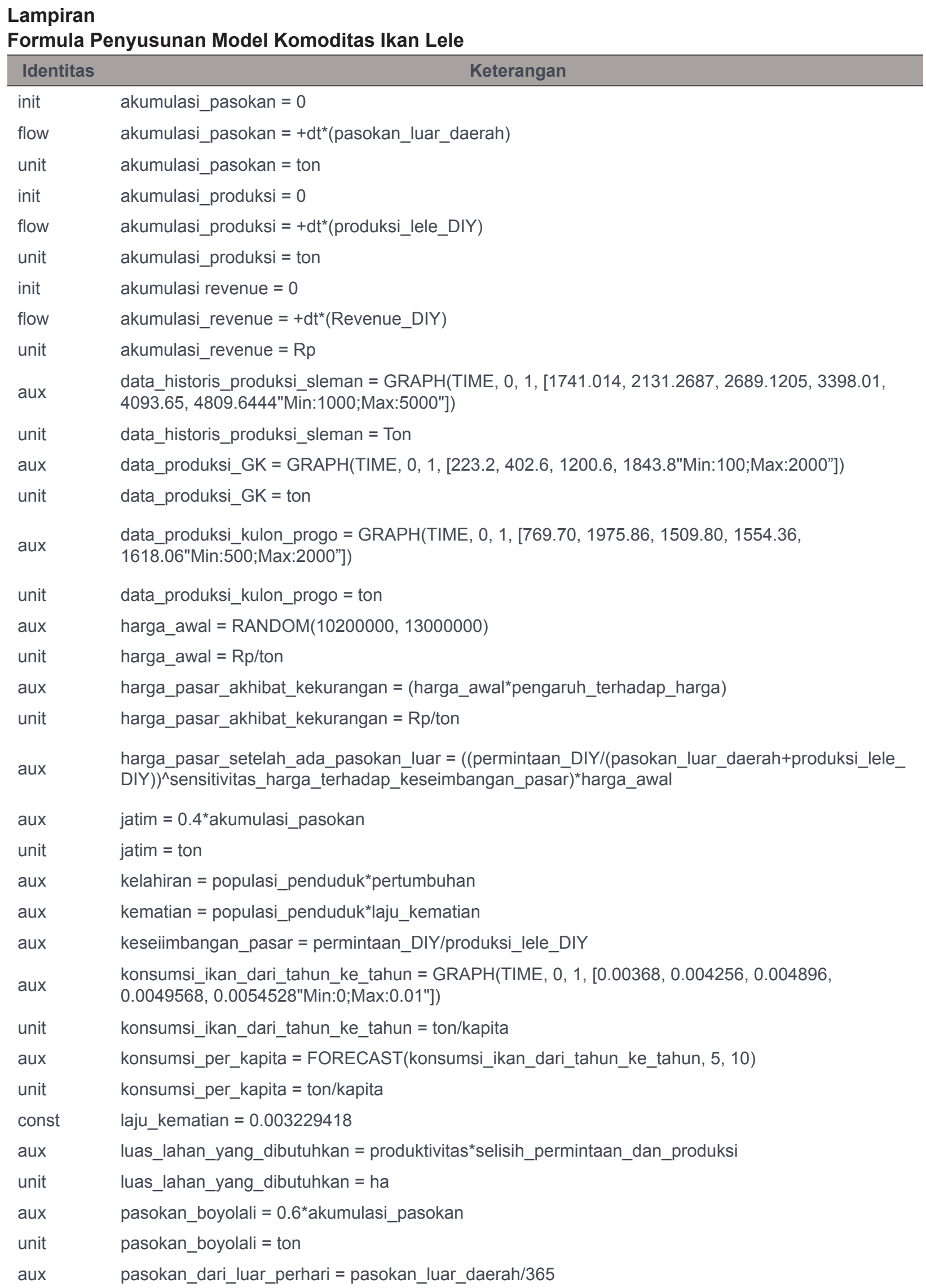




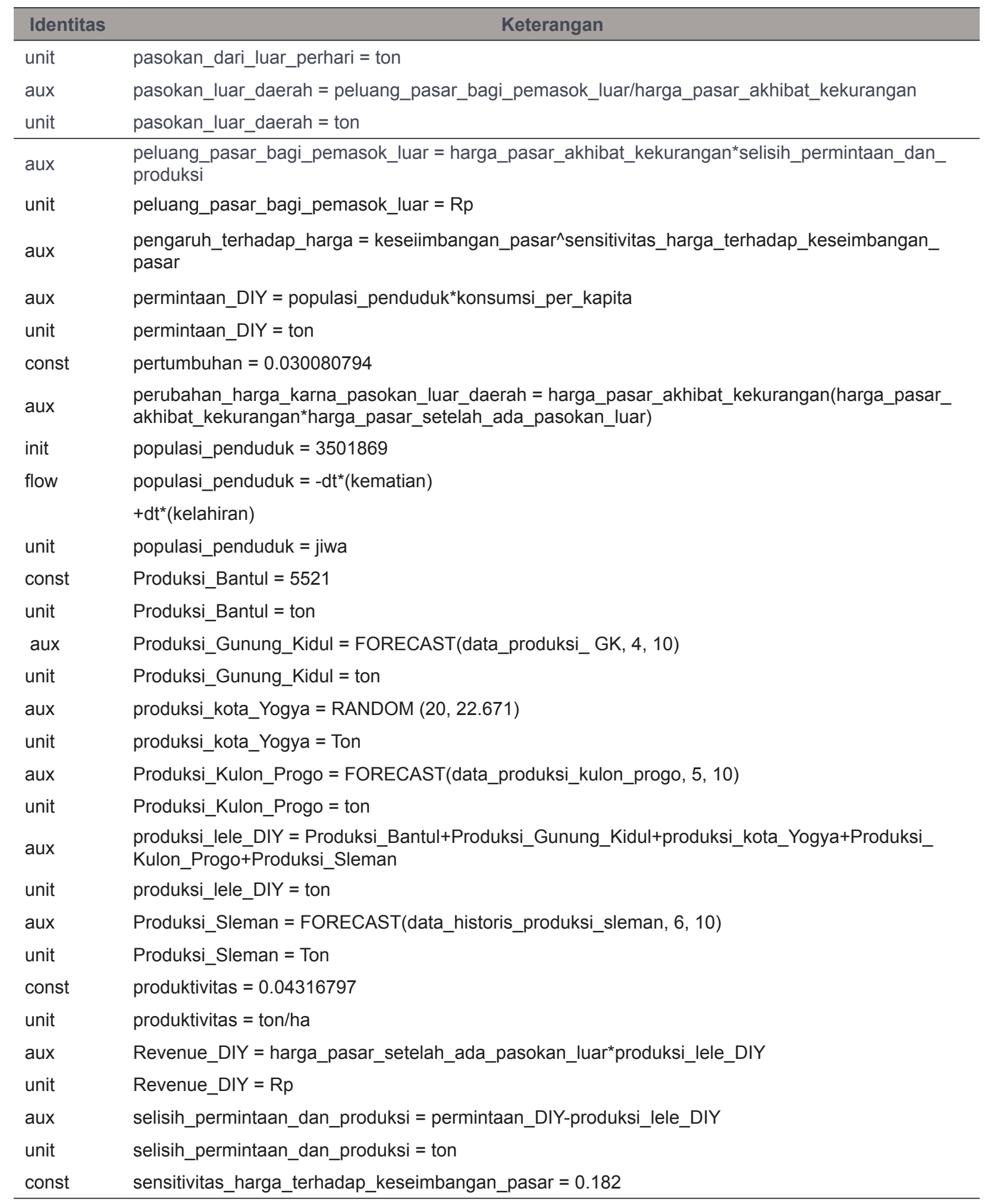

